\title{
Word Recognition Materials for Native Speakers of Taiwan Mandarin
}

Shawn L. Nissen

Shawn_Nissen@byu.edu

Richard W. Harris

Alycia Dukes

Follow this and additional works at: https://scholarsarchive.byu.edu/facpub

Part of the Communication Sciences and Disorders Commons

\section{Original Publication Citation}

Nissen, S. L., Harris, R. W., \& Dukes, A. (28). Word recognition materials for native speakers of Taiwan Mandarin. The American Journal of Audiology, 17, 68-79.

\section{BYU ScholarsArchive Citation}

Nissen, Shawn L.; Harris, Richard W.; and Dukes, Alycia, "Word Recognition Materials for Native Speakers of Taiwan Mandarin" (2008). Faculty Publications. 188.

https://scholarsarchive.byu.edu/facpub/188 

Speakers of Taiwan Mandarin

\author{
Shawn L. Nissen \\ Richard W. Harris \\ Alycia Dukes \\ Brigham Young University, Provo, UT
}

\begin{abstract}
Purpose: To select, digitally record, evaluate, and psychometrically equate word recognition materials that can be used to measure the speech perception abilities of native speakers of Taiwan Mandarin in quiet.

Method: Frequently used bisyllabic words produced by male and female talkers of Taiwan Mandarin were digitally recorded and subsequently evaluated using 20 native listeners with normal hearing at 10 intensity levels $(-5$ to $40 \mathrm{~dB} \mathrm{HL})$ in increments of $5 \mathrm{~dB}$.

Results: Using logistic regression, 200 words with the steepest psychometric slopes were
\end{abstract}

\begin{abstract}
divided into 4 lists and 8 half-lists that were relatively equivalent in psychometric function slope. To increase auditory homogeneity of the lists, the intensity of words in each list was digitally adjusted so that the threshold of each list was equal to the midpoint between the mean thresholds of the male and female half-lists. Conclusions: Digital recordings of the word recognition lists and the associated clinical instructions are available on CD upon request.
\end{abstract}

Key Words: word recognition, Taiwan Mandarin, Chinese, speech audiometry, psychometric function
$\mathrm{T}$ he purpose of the following study was to develop and evaluate word recognition materials that can be used to assess the hearing abilities of individuals who speak Taiwan Mandarin, a regional dialect of Mandarin Chinese. Speech audiometry materials have been recently developed for Pǔtōnghuà (Nissen, Harris, Jennings, Eggett, \& Buck, 2005a, 2005b), a standard dialect of Mandarin commonly spoken in mainland China. However, there are many individuals living throughout the world who speak dialects of Mandarin that are linguistically distinct from Pǔtōnghuà; for these individuals, such speech audiometry materials may not provide a valid and accurate evaluation of their hearing abilities.

Previous findings from Weisleder and Hodgson (1989) indicate that regional differences in dialect between the talker and listener may affect the validity of word recognition results. The authors evaluated the performance of four Spanish word recognition lists with listeners from differing regional linguistic backgrounds. The lists were produced by a talker of Mexican origin, whereas the listeners were from Mexico, Panama, Venezuela, Spain, Honduras, and Columbia. It was found that listeners originating from the same country as the talker performed better than participants from the other Spanish-speaking countries, even though all the listeners reported the talker to be mutually intelligible. Differences between listener performances were most pronounced in more difficult listening environments. These findings indicate that even small differences in regional dialect between the talker and listener may affect the validity of acquired word recognition results.

Mandarin is a term that refers to a group of Chinese dialects spoken in many different areas of the world, many of which exhibit unique linguistic characteristics and distinct regionalisms. In general, dialects of Mandarin are considered tonal, in that words and meaningful morphological units are formed by combining a comparatively basic segmental structure with an overriding suprasegmental tone. Individual syllables generally have an optional initial consonant followed by a nuclear vowel that can occur as a monophthong, diphthong, or in some cases a triphthong (e.g., /i, ou, iou/; Chao, 1968). Some syllables have a coda consisting of a relatively limited set of nasals. In addition, Mandarin is an isolated language, whereby each orthographic character is a free morpheme that carries unique meaning (C. N. Li \& Thompson, 1987). In theory, each Mandarin character has unique meaning and can stand alone; however, the majority of the lexicon is composed of polysyllabic compound words (Zhou \& Marslen-Wilson, 1995).

While Taiwan Mandarin and Pǔtōnghuà are considered by linguists to be generally mutually intelligible with regard to expressed meaning, each dialect contains marked differences in syntax, lexicon, phonology, and orthographic representation 
(D. C. C. Li, 1983). Syntactically, Taiwan Mandarin differs from Pǔtōnghuà in the tendency of speakers to mark the contrast between perfective and imperfective cases, and habitual and future action, yet to neutralize differences between present and past action verbs (Cheng, 1985). In addition, the two dialects exhibit differences in the use of auxiliary verbs and common verbs such as have, come, and go (Cheng, 1985; D. C. C. Li, 1985). There are also differences in the lexicon of each dialect. For example, the Taiwan Mandarin word cùantōng (窣通), meaning "an exchange," is often ambiguous for many speakers of Pǔtōnghuà, which more commonly uses vocabulary such as jiāo liú (交流) or hùhùan (互換) to express a similar meaning (D. C. C. Li, 1985). Phonologically, the dialects differ in terms of consonant, vowel, and tone production. Taiwan Mandarin often replaces retroflex initials with dentals, switches $\mathrm{h} /$ and $/ \mathrm{y} /$ in the final position of words, and commonly merges vowel categories (e.g., /y/ with/i/). Some researchers have even suggested that the vowel structure of Taiwan Mandarin is different from that of other dialects of Mandarin spoken in mainland China (Wan \& Jaeger, 2003). When compared with other dialects of Mandarin, Taiwan Mandarin has been characterized as having a relatively low tone registry and a less frequent use of a neutral or fifth tone for unstressed syllables (Fon \& Chiang, 1999; Kubler, 1985; Peng, 1991). In addition, two different orthographic systems are often used to visually represent Pǔtōnghuà and Taiwan Mandarin. Traditional Chinese characters are utilized in Taiwan, Hong Kong, and many overseas communities, whereas in the 1950s, mainland China officially adopted a writing system of simplified characters (C. N. Li \& Thompson, 1987).

The origin of linguistic differences between the two dialects is due in part to the geographic isolation and political separation of Taiwan from mainland China. Dialectal differences between Taiwan Mandarin and Pǔtōnghuà may also be a result of a period of Japanese colonization prior to World War II and the influence of indigenous speakers (e.g., Taiwanese). The national language of Taiwan was changed to Taiwan Mandarin in 1949, despite a large number of native speakers of Japanese, Taiwanese, and Beijing Mandarin (Lee, 1981). From 1949 to 1960 , the Taiwan provincial government campaigned to promote the use of Taiwan Mandarin as the sole means of communication for instruction in the school systems in Taiwan. These sociolinguistic factors have led to a dialect of Mandarin that is unique to the native speakers of Taiwan. (For a more comprehensive discussion about the linguistic differences between the two dialects and their origins, see Cheng, 1985; Fon \& Chiang, 1999; D. C. C. Li, 1983; Nissen, Harris, \& Slade, 2007; Peng, 1991.)

An appropriate hearing evaluation for an individual from Taiwan should involve speech audiometry materials in his or her specific regional dialect. Thus, the aim of this study was to develop high-quality digitally recorded word recognition materials in Taiwan Mandarin. The specific objectives were as follows: (a) to identify one female individual and one male individual from Taiwan who spoke Mandarin Chinese with a standard Taiwan dialect to serve as talkers for the recordings; (b) to compose a list of familiar bisyllabic Mandarin words to be used in word recognition testing; (c) to create high-quality digital recordings of the bisyllabic words; (d) to collect normative data on the bisyllabic words; and (e) to construct psychometrically equivalent lists (50 words each) and half-lists (25 words each) of bisyllabic Mandarin words from both the female and male talkers.

\section{Method \\ Participants}

Twenty native speakers of Taiwan Mandarin (3 male and 17 female) ranging in age from 18 to 39 years $(M=25.8$ years) participated in evaluating the materials developed in this study. Participants were recruited within the United States and had recently originated from various regions of Taiwan (e.g., Taibei, Taichung, Kaohsiung). In addition, all participants reported speaking a standard dialect of Taiwan Mandarin on a daily basis since arriving in the United States. All of the participants were found to have pure-tone air-conduction thresholds $\leq 15 \mathrm{~dB} \mathrm{HL}$ at octave and midoctave frequencies from 125 to $8000 \mathrm{~Hz}$ and static acoustic admittance between 0.3 and 1.4 mmhos with peak pressure between -100 and +50 daPa (American Speech-Language-Hearing Association, 1990; Roup, Wiley, Safady, \& Stoppenbach, 1998). The mean pure-tone average (arithmetic average of pure-tone thresholds at 500, 1000, and $2000 \mathrm{~Hz}$ ) for the 20 participants was $5.0 \mathrm{~dB}$ HL. Each participant also passed a screening test, which included an otoscopic evaluation, an ipsilateral acoustic reflex of $95 \mathrm{~dB}$ HL or better in the test ear at $1000 \mathrm{~Hz}$, and the signing of an informed consent form.

\section{Materials}

Word lists. Monosyllabic words are often used for word recognition testing in English; however, this study utilized bisyllabic words in developing materials for speakers of Taiwan Mandarin, for the following reasons: First, previous studies involving the development of speech audiometry materials using native Mandarin speakers from mainland China found that bisyllabic words have relatively steeper mean psychometric slopes (Nissen et al., 2005a, 2005b). Second, although each written Chinese character can express unique lexical meaning, the majority word type in spoken Mandarin (approximately $73.6 \%$ ) is bisyllabic (Institute of Language Teaching and Research, 1986). Finally, the same pronunciation (e.g., shi) is often used for multiple different Chinese characters; thus, it would be inconvenient to evaluate a participant's written responses to monosyllabic Mandarin word lists (Mathews, 1944).

A preliminary word corpus of 300 frequently used bisyllabic words was drawn from the Academia Sinica Balanced Corpus of Modern Chinese (Academia Sinica Computing Center, 1997). This corpus contains approximately 5 million words, balanced across the topics of philosophy, science, society, art, life, and literature. According to the Sinica corpus, the initial set of words selected for this study were all ranked within the top 400 most frequently used modern Chinese words, with an average frequency percentage of .0004, ranging from a low of .0002 to a high of .0038 . These words were then rated by 3 native speakers of Taiwan Mandarin on a scale of 1 to 5 based on how familiar a word would be to a Mandarin speaker from Taiwan $(1=$ extremely familiar, $2=$ very familiar, 3 = somewhat familiar, 4 = infrequently 
used, and $5=$ rarely used ). Of the 300 original bisyllabic words, 60 words were eliminated from final evaluation for the following reasons: (a) The specific word was not rated as extremely familiar by any of the native judges, (b) it was judged to be culturally or politically insensitive, or (c) it had the same pronunciation but different meaning (homophonic words) as another word in the corpus.

Talkers. Initial audio recordings of conversational speech were produced by 6 native talkers of Taiwan Mandarin ( 3 female and 3 male), all of whom originated from Taiwan and reported speaking a standard dialect of Taiwan Mandarin. A panel of 8 native speakers then evaluated the speech production of each of the 6 talkers. The native judges were instructed to rank the recordings of each talker from best to worst based on the perceived clarity of pronunciation, vocal quality, and standard Taiwan Mandarin dialect. The highest ranked male and female speakers were chosen as the talkers for all subsequent recordings.

Recordings. The talker recordings were made in a doublewalled sound booth located on the Brigham Young University campus in Provo, UT. A Larson Davis Model 2541 microphone, positioned approximately $15 \mathrm{~cm}$ from the talker at a $0^{\circ}$ azimuth and covered by a 7.62-cm windscreen, was utilized for all recordings. The microphone signal was amplified by a Larson Davis Model 900B microphone preamplifier, which was coupled to a Larson Davis Model 2200C preamplifier power supply. An Apogee AD-8000 analog-to-digital converter was used to digitize the audio signals, which were subsequently stored on a hard drive for later editing. A 44.1-kHz sampling rate with 24-bit quantization was used for all recordings, and every effort was made to utilize the full range of the 24-bit analog-to-digital converter.

The talkers were asked to pronounce each bisyllabic word at least four times. To avoid possible list effects and declination of intonation, the first and last repetitions of each word were excluded from the study. A native judge then rated the medial repetitions of each bisyllabic word for perceived quality of production, and the highest rated production of each word was selected for further evaluation. Any words that were judged to be poorly recorded were rerecorded or eliminated from the study prior to listener evaluation. The intensity of each bisyllabic word to be included in the listener evaluation was then edited as a single utterance using Sadie Disk Editor software (Studio Audio \& Video, 2004) to yield the same equivalent continuous sound level (Leq) as that of a $1-\mathrm{kHz}$ calibration tone using a Larson Davis Model 824 sound level meter.

\section{Procedures}

The randomization and presentation of the words were controlled using custom software. The experimental stimuli were routed from a computer hard drive to the external input of a Grason-Stadler Model 1761 audiometer using a Lynx L22 sound card. The stimuli were then routed via TDH-50P headphones from the audiometer to the participants. Testing was conducted in a double-walled sound suite meeting American National Standards Institute (ANSI S3.1-1999) standards for maximum permissible ambient noise levels for the ears-not-covered condition using one third octave-band measurements (ANSI, 1999). Prior to each testing session, the inputs to the audiometer were calibrated to $0 \mathrm{VU}$ using the $1-\mathrm{kHz}$ calibration tone through customized computer software. In accordance with ANSI S3.6-2004 standards (ANSI, 2004), the audiometer was also calibrated weekly during and at the conclusion of data collection. No changes in calibration were necessary throughout the course of data collection.

\section{Evaluation of Bisyllabic Words}

The participants were not familiarized with the bisyllabic words prior to testing. The 240 bisyllabic words were randomly grouped into 10 lists of 24 words each. These 10 lists were used for presentation to the first 10 participants. The 240 words were then randomly combined in a second group of 10 different lists for presentation to the next group of 10 participants. Ten presentation levels were selected for the lists: -5 to $40 \mathrm{~dB}$ HL in 5-dB steps. One list was presented at each level. The order of the presentation of the lists and the order of the words within the list were randomized for each participant. Each word was presented an equal number of times at each intensity level across the entire participant population. Prior to administration of the word recognition test, the following instructions were given to the participants in Mandarin:

You will hear bisyllabic words at several different loudness levels. At the very soft levels it may be difficult for you to hear the words. Please listen carefully and repeat the words you hear. If you are unsure of the word, you are encouraged to guess. If you have no guess, please remain quiet until the next word is presented. Do you have any questions?

The accuracy of the participants' verbal responses was judged to be correct or incorrect by a native speaker of Taiwan Mandarin who was highly familiar with the word corpus and the testing procedures. An orthographic display of each test item was made available to the native judge during and after each stimulus presentation. The scoring of each test item was immediately recorded by the native judge using custom software.

\section{Results}

Word recognition scores have been traditionally derived by utilizing full word lists consisting of 50 test items. However, some audiologists utilize only half of the 50 full-list items to reduce clinical testing time and decrease the influence of patient fatigue (Penrod, 1994). To accommodate both methods of assessment, the final word recognition materials were organized into four lists (50 words each) and eight half-lists ( 25 words each) for both the male and female talker recordings.

The 200 words with the greatest number of correct identifications were selected and subsequently divided into four counterbalanced lists of 50 words each through random block assignment. This was accomplished by first assigning a ranking to each bisyllabic word based on the number of times it was correctly identified across all participants and intensity levels. The first four words from the rank-ordered list of 200 words were then randomly assigned to one of the four 
lists. This list assignment procedure was repeated with the next four rank-ordered words until each of the four word recognition lists contained 50 words each. Eight half-lists were created from the four word recognition lists by dividing each list into 25 consecutive pairs of words based on their relative position in the list. For example, Pair 1 consisted of the first and second word in the list, Pair 2 the third and fourth word, and so on. The first word from the first pair was then allocated to Half-List A and the second to Half-List B. For each subsequent pair, this allocation was reversed. The male and female word recognition lists (Appendix A) and half-lists (Appendix B) are provided in both traditional characters and Hanyu Pinyin romanization.

The combined dichotomous perception data from each word in a list or half-list were analyzed with logistic regression to calculate regression slopes and intercepts for each of the four lists and eight half-lists for both male and female talker recordings, which are presented in Tables 1 and 2, respectively. Percentage correct recognition values were calculated for each list and half-list by inserting the regression slope and intercept values into a modified logistic regression equation (Equation 1). This equation is designed to calculate percentage of correct performance at any specified intensity level. In Equation 1, $P$ is percentage of correct recognition, $a$ is the regression intercept, $b$ is the regression slope, and $i$ is the presentation intensity level in $\mathrm{dB}$ HL.

$$
P=\left(1-\frac{\exp (a+b \times i)}{1+\exp (a+b \times i)}\right) \times 100 \text {. }
$$

The percentage of correct word recognition was predicted for each of the bisyllabic lists and half-lists at a range of intensity levels ( -8 to $40 \mathrm{~dB} \mathrm{HL}$ in $2-\mathrm{dB}$ increments). A psychometric function for each list and half-list was created using these predicted percentages of word recognition. In addition, the threshold (presentation intensity required for $50 \%$ word recognition), the slope at threshold, and the slope from $20 \%$ to $80 \%$ were calculated for each of the bisyllabic lists and half-lists by inserting the desired proportions into Equation 2. In Equation 2, $i$ is the presentation level in $\mathrm{dB} \mathrm{HL}$, $p$ is the proportion of correct recognition, $a$ is the regression intercept, and $b$ is the regression slope.

$$
i=\frac{\log \frac{p}{1-p}-a}{b} .
$$

As shown in Table 1, for the male talker recordings, the psychometric function slopes at the $50 \%$ location ranged from $8.7 \%$ to $10.2 \% / \mathrm{dB}(M=9.6 \% / \mathrm{dB})$ for the lists and from $8.4 \%$ to $11.3 \% / \mathrm{dB}(M=9.6 \% / \mathrm{dB})$ for the half-lists. The slope values for the female talker recordings are found in Table 2, which range from $7.6 \%$ to $8.2 \% / \mathrm{dB}(M=7.8 \% / \mathrm{dB})$ for the lists and from $7.2 \%$ to $8.6 \% / \mathrm{dB}(M=7.9 \% / \mathrm{dB})$ for the halflists. Slopes of the psychometric functions were slightly lower when measured from the $20 \%$ to $80 \%$ points of the functions instead of calculating the slopes at the threshold midpoint, with slope values ranging from $7.6 \%$ to $8.8 \% / \mathrm{dB}$ $(M=8.3 \% / \mathrm{dB})$ for the male talker lists and from $7.3 \%$ to $9.8 \% / \mathrm{dB}(M=8.3 \% / \mathrm{dB})$ for the half-lists; for the female talker

\begin{tabular}{|c|c|c|c|c|c|c|}
\hline List & Intercept $^{\mathrm{a}}$ & Slope ${ }^{b}$ & Slope at $50 \%^{\mathrm{c}}$ & Slope from $20 \%$ to $80 \%{ }^{d}$ & $50 \%$ threshold $^{\mathrm{e}}$ & Change to midpoint ${ }^{f}$ \\
\hline 1 & 2.2178 & -0.4078 & 10.2 & 8.8 & 5.4 & 1.0 \\
\hline 2 & 2.2178 & -0.4078 & 10.2 & 8.8 & 5.4 & 1.0 \\
\hline 3 & 1.8779 & -0.3496 & 8.7 & 7.6 & 5.4 & 0.9 \\
\hline 4 & 1.9625 & -0.3649 & 9.1 & 7.9 & 5.4 & 0.9 \\
\hline$M$ & 2.0690 & -0.3825 & 9.6 & 8.3 & 5.4 & 0.9 \\
\hline Minimum & 1.8779 & -0.4078 & 8.7 & 7.6 & 5.4 & 0.9 \\
\hline Maximum & 2.2178 & -0.3496 & 10.2 & 8.8 & 5.4 & 1.0 \\
\hline Range & 0.3399 & 0.0582 & 1.5 & 1.3 & 0.1 & 0.1 \\
\hline$S D$ & 0.1753 & 0.0299 & 0.7 & 0.6 & 0.0 & 0.0 \\
\hline $1 \mathrm{~A}$ & 2.0085 & -0.3733 & 9.3 & 8.1 & 5.4 & 0.9 \\
\hline $1 \mathrm{~B}$ & 2.4885 & -0.4531 & 11.3 & 9.8 & 5.5 & 1.0 \\
\hline $2 \mathrm{~A}$ & 2.0573 & -0.3822 & 9.6 & 8.3 & 5.4 & 0.9 \\
\hline $2 B$ & 2.4104 & -0.4389 & 11.0 & 9.5 & 5.5 & 1.0 \\
\hline $3 \mathrm{~A}$ & 1.8019 & -0.3359 & 8.4 & 7.3 & 5.4 & 0.9 \\
\hline 3B & 1.9625 & -0.3649 & 9.1 & 7.9 & 5.4 & 0.9 \\
\hline $4 \mathrm{~A}$ & 1.8779 & -0.3496 & 8.7 & 7.6 & 5.4 & 0.9 \\
\hline 4B & 2.0573 & -0.3822 & 9.6 & 8.3 & 5.4 & 0.9 \\
\hline$M$ & 2.0830 & -0.3850 & 9.6 & 8.3 & 5.4 & 0.9 \\
\hline Minimum & 1.8019 & -0.4531 & 8.4 & 7.3 & 5.4 & 0.9 \\
\hline Maximum & 2.4885 & -0.3359 & 11.3 & 9.8 & 5.5 & 1.0 \\
\hline Range & 0.6866 & 0.1172 & 2.9 & 2.5 & 0.1 & 0.1 \\
\hline$S D$ & 0.2432 & 0.0410 & 1.0 & 0.9 & 0.1 & 0.1 \\
\hline
\end{tabular}

Table 1. Mean performance of Taiwan Mandarin male bisyllabic lists and half-lists.

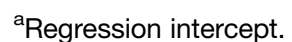

${ }^{\mathrm{b}}$ Regression slope.

CPsychometric function slope $(\% / \mathrm{dB})$ at $50 \%$ was calculated from $49.999 \%$ to $50.001 \%$.

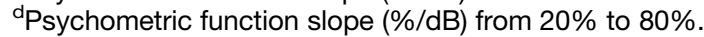

Intensity required for $50 \%$ intelligibility.

${ }^{\mathrm{f}}$ Change in intensity required to adjust the $50 \%$ threshold of a list to the mean $50 \%$ threshold for male and female lists ( $4.5 \mathrm{~dB} \mathrm{HL}$ ). 
Table 2. Mean performance of Taiwan Mandarin female bisyllabic lists and half-lists.

\begin{tabular}{|c|c|c|c|c|c|c|}
\hline List & Intercept $^{\mathrm{a}}$ & Slope ${ }^{b}$ & Slope at $50 \%^{c}$ & Slope from $20 \%$ to $80 \%{ }^{d}$ & $50 \%$ threshold $^{e}$ & Change to midpoint ${ }^{f}$ \\
\hline 1 & 1.0684 & -0.3054 & 7.6 & 6.6 & 3.5 & -1.0 \\
\hline 2 & 1.1768 & -0.3288 & 8.2 & 7.1 & 3.6 & -0.9 \\
\hline 3 & 1.0794 & -0.3082 & 7.7 & 6.7 & 3.5 & -1.0 \\
\hline 4 & 1.1157 & -0.3133 & 7.8 & 6.8 & 3.6 & -0.9 \\
\hline$M$ & 1.1101 & -0.3139 & 7.8 & 6.8 & 3.5 & -0.9 \\
\hline Minimum & 1.0684 & -0.3288 & 7.6 & 6.6 & 3.5 & -1.0 \\
\hline Maximum & 1.1768 & -0.3054 & 8.2 & 7.1 & 3.6 & -0.9 \\
\hline Range & 0.1083 & 0.0233 & 0.6 & 0.5 & 0.1 & 0.1 \\
\hline$S D$ & 0.0488 & 0.0104 & 0.3 & 0.2 & 0.0 & 0.0 \\
\hline $1 \mathrm{~A}$ & 1.1137 & -0.3169 & 7.9 & 6.9 & 3.5 & -1.0 \\
\hline $1 \mathrm{~B}$ & 1.0265 & -0.2950 & 7.4 & 6.4 & 3.5 & -1.0 \\
\hline $2 \mathrm{~A}$ & 1.2164 & -0.3434 & 8.6 & 7.4 & 3.5 & -0.9 \\
\hline $2 \mathrm{~B}$ & 1.1412 & -0.3156 & 7.9 & 6.8 & 3.6 & -0.9 \\
\hline $3 A$ & 1.1627 & -0.3295 & 8.2 & 7.1 & 3.5 & -0.9 \\
\hline $3 B$ & 1.0067 & -0.2900 & 7.3 & 6.3 & 3.5 & -1.0 \\
\hline $4 \mathrm{~A}$ & 1.2164 & -0.3434 & 8.6 & 7.4 & 3.5 & -0.9 \\
\hline $4 \mathrm{~B}$ & 1.0332 & -0.2892 & 7.2 & 6.3 & 3.6 & -0.9 \\
\hline$M$ & 1.1146 & -0.3154 & 7.9 & 6.8 & 3.5 & -0.9 \\
\hline Minimum & 1.0067 & -0.3434 & 7.2 & 6.3 & 3.5 & -1.0 \\
\hline Maximum & 1.2164 & -0.2892 & 8.6 & 7.4 & 3.6 & -0.9 \\
\hline Range & 0.2097 & 0.0542 & 1.4 & 1.2 & 0.1 & 0.1 \\
\hline$S D$ & 0.0843 & 0.0224 & 0.6 & 0.5 & 0.0 & 0.0 \\
\hline \multicolumn{7}{|c|}{ 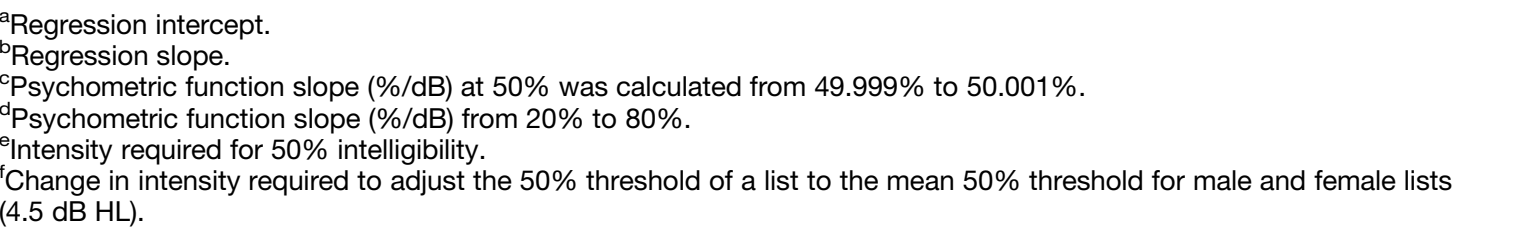 } \\
\hline
\end{tabular}

lists, values ranged from $6.6 \%$ to $7.1 \% / \mathrm{dB}(M=6.8 \% / \mathrm{dB})$ and from $6.3 \%$ to $7.4 \% / \mathrm{dB}(M=6.8 \% / \mathrm{dB})$ for the half-lists.

A logistic regression yielding a chi-square statistic was utilized to investigate whether there were any significant differences among the lists or half-lists for each talker. In terms of statistical power, the chi-square analysis for the full lists was able to detect a 10\% difference in correct responses between lists with a probability of .997 and for the half-lists a $10 \%$ difference in correct responses between lists with a probability of .913. The results of the analysis indicated that there were no significant differences among the 50 -word lists for the male and female talkers, $\chi^{2}(3, N=20)=1.97, p=.578$, and $\chi^{2}(3, N=20)=0.26, p=.965$, respectively. Results also indicated that there were no significant differences found among the 25-word half-lists for the male and female talkers, $\chi^{2}(7, N=20)=3.75, p=.808$, and $\chi^{2}(7, N=20)=.98$, $p=.995$, respectively. There were also no significant withintalker Intensity $\times$ List interactions noted.

Although there were no statistically significant differences found among the word recognition lists or half-lists for each talker, digital intensity-level adjustments were made to each list using Sadie Disk Editor software (Studio Audio \& Video, 2004) to increase the psychometric equivalency of the materials. The intensity of each word from the male and female bisyllabic lists and half-lists was adjusted digitally so that the $50 \%$ threshold of each list was equal to the midpoint (4.5 dB HL) between the mean threshold of the eight male half-lists and the mean threshold of the eight female half-lists.
Lists of the digital adjustments for both the male and female talker lists are presented in Tables 1 and 2. The psychometric functions for the lists and half-lists after intensity adjustment are illustrated in Figure 1. Figure 2 contains mean psychometric functions for the combined male and combined female bisyllabic lists both before and after intensity adjustment to equate performance.

\section{Discussion}

The purpose of the current study was to construct a set of psychometrically equivalent bisyllabic Taiwan Mandarin word recognition lists and half-lists for use in word recognition testing. As shown in Figures 1 and 2, the developed materials were relatively homogenous in performance with regard to audibility and psychometric function slope. Results from a two-way chi-square analysis indicated that there were no statistically significant differences among lists or half-lists within the male or female talker materials. Some differences were found between the male and female talker materials in terms of mean performance, with the psychometric function slopes at threshold (50\%) and from $20 \%$ to $80 \%$ for both the lists and half-lists being steeper for the male recordings when compared with the female recordings.

When measured from the $20 \%$ to $80 \%$ points of the psychometric function, the Taiwan Mandarin word recognition lists developed in this study were found to have slightly higher slopes $(8.3 \% / \mathrm{dB}$ for the male talker and $6.8 \% / \mathrm{dB}$ for 
Figure 1. Psychometric functions for the four Taiwan Mandarin bisyllabic lists and eight half-lists for male talker and female talker recordings after intensity adjustments to produce $50 \%$ performance at $4.5 \mathrm{~dB} \mathrm{HL}$.

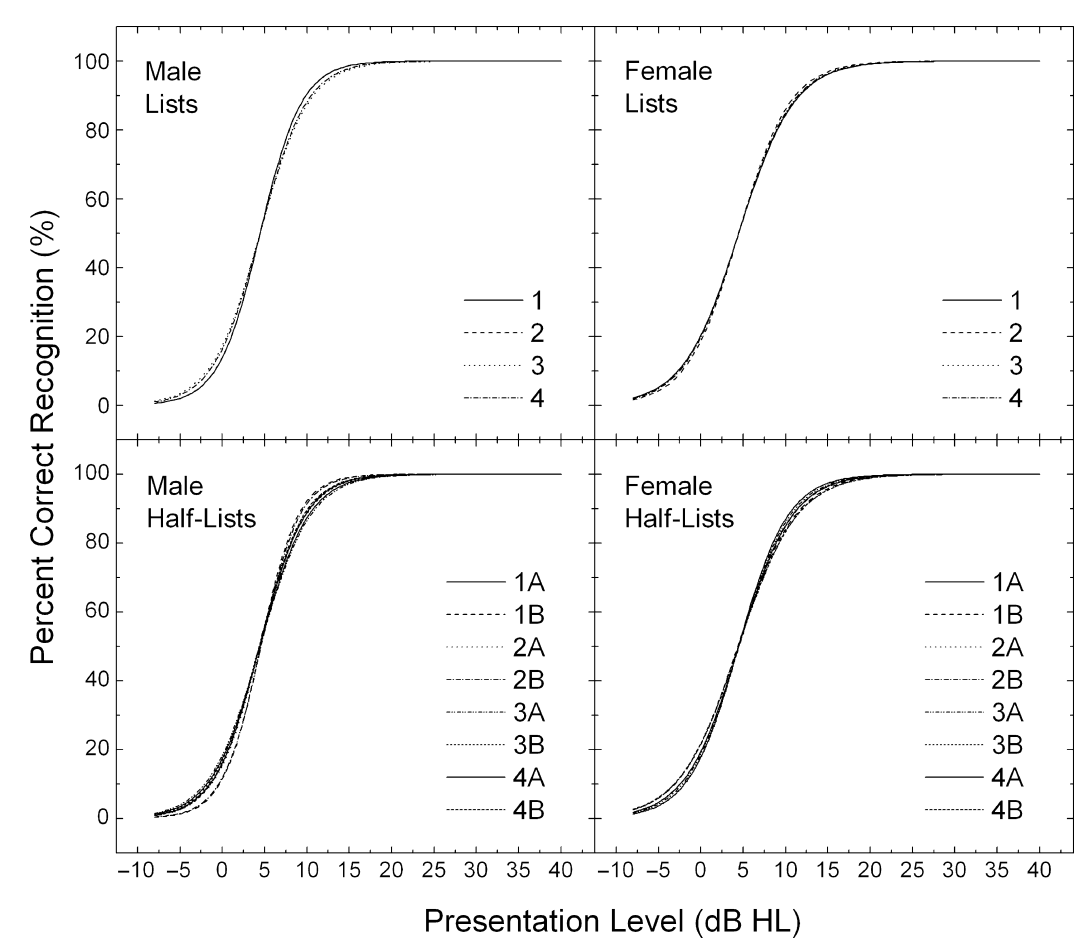

Figure 2. Mean psychometric functions for male and female Taiwan Mandarin talker bisyllabic lists before and after intensity adjustment.

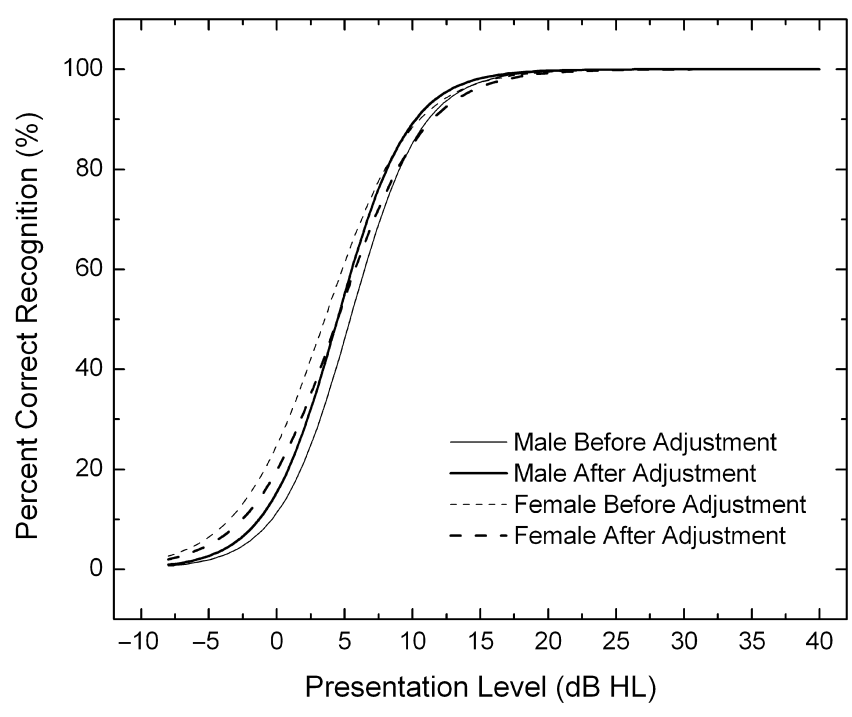

the female talker) than values reported for several types of English word recognition materials. Previous research has reported that the Northwestern University Auditory Test No. 6 (NU-6) and Central Institute for the Deaf (CID) W-22 English word lists have mean slopes of $4.2 \% / \mathrm{dB}$ and $4.6 \% / \mathrm{dB}$, respectively (Beattie, Edgerton, \& Svihovec, 1977), while more recently Wilson and Oyler (1997) have reported mean values of $4.4 \% / \mathrm{dB}$ and $4.8 \% / \mathrm{dB}$.

Of particular interest is how the psychometric slope values of these materials will compare with previously developed word recognition materials for speakers of Pǔtōnghuà (Nissen et al., 2005a), a regional dialect of Mandarin spoken in mainland China. In terms of list and half-list performance, the materials developed for Taiwan Mandarin speakers exhibit slightly steeper psychometric function slopes than the materials developed in Pǔtōnghuà. The overall mean psychometric slope values at threshold (50\%) averaged across the male and female talkers was $7.8 \% / \mathrm{dB}$ for Pǔtōnghuà and $8.7 \% / \mathrm{dB}$ for Taiwan Mandarin materials (lists and half-lists). The mean slopes from $20 \%$ to $80 \%$ in Pǔtōnghuà were reported as $6.8 \% / \mathrm{dB}$ as compared to $7.5 \% / \mathrm{dB}$ for the materials developed in Taiwan Mandarin.

A possible reason why the psychometric slopes of Taiwan Mandarin were higher than those of English may be due to the different underlying structure of the language (e.g., Mandarin is considered a tonal language). In addition, the present study utilized bisyllabic words rather than monosyllabic words, as are typically used in English word recognition materials, thereby providing the listeners with more acoustic information 
with which to perceive the words. The relatively small differences in psychometric slope found between the Taiwan Mandarin materials developed in this study and previously developed materials in Pǔtōnghuà may be due to individual variation in the dialect or articulation of the talkers or in the speech perception abilities of the listeners. Although Pǔtōnghuà is considered to be the standard dialect of Mandarin in mainland China and is commonly utilized in media broadcasting (Campbell, 1991), a listener's native dialect may contain subtle regionalisms that differ from the pronunciation of the talker, even if both live within the same geographic area.

Although the overall psychometric slope values are similar between the two dialects, it would be of interest to conduct a direct examination of how speakers of Pǔtōnghuà (mainland China) would perform on these Taiwan Mandarin word recognition materials and vice versa. To date, there has been limited research on how a regional dialect might affect word recognition testing (Schneider, 1992; Weisleder \& Hodgson, 1989). In the study by Weisleder and Hodgson, findings indicated that a regional dialect can affect the validity of word recognition testing in Spanish; however, Schneider found the effects of regional dialect to not significantly affect the speech recognition scores of Spanish-speaking children. Thus, there remains a need to investigate the validity of using materials from a nonregional, yet mutually intelligible, dialect to evaluate an individual's word recognition abilities in Mandarin. In addition, it would be of value to determine whether a native speaker of one Mandarin dialect is able to accurately administer and score word recognition testing for speakers of a different regional dialect.

This study is an initial attempt to create and evaluate materials for word recognition testing in Taiwan Mandarin; however, we readily acknowledge that there remains a need to continue to examine the effectiveness of these materials and to develop additional types of speech audiometry materials in Taiwan Mandarin. For example, the word recognition lists developed in this study were evaluated using listeners with normal hearing in a quiet environment. It is possible that list performance will vary in listeners with a hearing impairment or in a noisy environment (e.g., Jerger, 2006; McArdle \& Wilson, 2006; Wilson \& McArdle, 2005). In addition, the test-retest reliability and confidence limits of these materials require further evaluation.

The aim of this study was to produce speech audiometry materials for adult listeners; thus, the validity of using these materials for younger individuals is unknown. Some of the lexical items contained within the lists and half-lists may be unfamiliar to children, such as the words 經濟 (economy) or 政治 (politics). Ashoor and Prochazka (1985) developed Arabic speech audiometry materials that were created specifically for children. These materials were selected from children's books and evaluated by younger listeners. It is evident that the materials developed in this study need further examination to determine whether they are appropriate for children.

Despite the limitations mentioned above, we believe the creation and evaluation of these materials are an essential step in providing audiologists the tools to evaluate the hearing abilities of speakers of Taiwan Mandarin in a linguistically appropriate manner. Although pure-tone testing is a quick and often reliable method to measure frequency-specific information about a patient's hearing impairment, a more comprehensive audiologic evaluation often includes measuring an individual's ability to perceive and process speech in his or her native language. Thus, the specific aims of this project were to create high-quality digitally recorded bisyllabic Taiwan Mandarin word recognition lists and half-lists of familiar words spoken by both a male and female talker. The recorded word lists and half-lists are relatively homogenous in regard to audibility and psychometric function slope. The threshold variability across the lists of each talker was reduced by digital adjustments in individual word intensity. (The speech audiometry materials developed and described in this study are contained on a CD titled Brigham Young University Taiwan Mandarin Speech Audiometry Materials; Harris \& Nissen, 2006.)

\section{Acknowledgments}

This project was made possible by funding from the David O. McKay School of Education at Brigham Young University. We would like to thank our two talkers, Chi-Hsun Hsieh and Min-min Tsai, and all the participants who participated in this study. We are grateful for the assistance provided by Adrienne Waters and Lindsay Downs in the selection of the word lists and by our research assistant Sabrina $\mathrm{Wu}$ in data collection. In addition, we would like to thank Chu-Ren Huang, Shu-Chuan Tseng, and Ru-Yng Chang for their assistance with electronic corpora.

\section{References}

Academia Sinica Computing Center. (1997). Academia sinica balanced corpus of modern Chinese. Retrieved September 6, 2007, from www.sinica.edu.tw/ftms-bin/kiwil/mkiwi.sh?language $=1$.

American National Standards Institute. (1999). Maximum permissible ambient noise levels for audiometric test rooms (ANSI S3.1-1999). New York: Author.

American National Standards Institute. (2004). Specifications for audiometers (ANSI S3.6-2004). New York: Author.

American Speech-Language-Hearing Association. (1990). Guidelines for screening for hearing impairments and middle-ear disorders. Asha, 32, 17-24.

Ashoor, A. A., \& Prochazka, T. (1985). Saudi Arabic speech audiometry for children. British Journal of Audiology, 19, 229-238.

Beattie, R. C., Edgerton, B. J., \& Svihovec, D. V. (1977). A comparison of the Auditec of St. Louis cassette recordings of NU-6 and CID W-22 on a normal-hearing population. Journal of Speech and Hearing Disorders, 42, 60-64.

Campbell, G. L. (1991). Compendium of the world's languages. New York: Routledge.

Chao, Y. R. (1968). A grammar of spoken Chinese. Berkeley: University of California Press.

Cheng, R. L. (1985). A comparison of Taiwanese, Taiwan Mandarin and Peking Mandarin. Language, 61, 352-377.

Fon, J., \& Chiang, W. (1999). What does Chao have to say about tones? A case study of Taiwan Mandarin. Journal of Chinese Linguistics, 27, 13-35.

Harris, R. W., \& Nissen, S. L. (2006). Brigham Young University Taiwan Mandarin speech audiometry materials [CD]. Provo, UT: Brigham Young University. 
Institute of Language Teaching and Research. (1986). A frequency dictionary of modern Chinese. Beijing, China: Beijing Language Institute Press.

Jerger, J. (2006). Are some more equal than others? Journal of the American Academy of Audiology, 17, 156.

Kubler, C. (1985). The development of Mandarin in Taiwan: A case study of language contact. Taipei, Taiwan: Student Book Company.

Lee, Y. L. (1981). A study on code-switching in Taiwan. Studies in Linguistic Science, 11, 121-136.

Li, C. N., \& Thompson, S. A. (1987). Chinese. In B. Comrie (Ed.), The world's major languages (pp. 811-833). New York: Oxford University Press.

Li, D. C. C. (1983). The sociolinguistic context of Mandarin in Taiwan: Trends and developments. In C. Chu, W. S. Coblin, \& F. F. Tsao (Eds.), Papers from the Fourteenth International Conference on Sino-Tibetan Languages and Linguistics (pp. 257-278). Taipei, Taiwan: Student Book Company.

Li, D. C. C. (1985). Problems and trends of standardization of Mandarin Chinese in Taiwan. Anthropological Linguistics, 27, $122-140$.

Mathews, R. H. (1944). Mathews' Chinese-English dictionary. Shanghai: China Inland Mission and Presbyterian Mission Press.

McArdle, R. A., \& Wilson, R. H. (2006). Homogeneity of the 18 QuickSIN lists. Journal of the American Academy of Audiology, 17, 157-167.

Nissen, S. L., Harris, R. W., Jennings, L., Eggett, D. L., \& Buck, H. (2005a). Psychometrically equivalent Mandarin bisyllabic speech discrimination materials spoken by male and female talkers. International Journal of Audiology, 44, 379-390.

Nissen, S. L., Harris, R. W., Jennings, L., Eggett, D. L., \& Buck, H. (2005b). Psychometrically equivalent trisyllabic words for speech reception threshold testing in Mandarin. International Journal of Audiology, 44, 391-399.

Nissen, S. L., Harris, R. W., \& Slade, K. (2007). Development of speech reception threshold materials for speakers of Taiwan Mandarin. International Journal of Audiology, 46, 449-458.

Peng, F. C. C. (1991). Historical linguistics and dialectology: A case study of Taiwan. Language Science, 13, 317-333.

Penrod, J. P. (1994). Speech threshold and word recognition/ discrimination testing. In J. Katz (Ed.), Handbook of clinical audiology (pp. 147-164). Baltimore: Williams \& Wilkins.
Roup, C. M., Wiley, T. L., Safady, S. H., \& Stoppenbach, D. T. (1998). Tympanometric screening norms for adults. American Journal of Audiology, 7, 55-60.

Schneider, B. S. (1992). Effect of dialect on the determination of speech-reception thresholds in Spanish-speaking children. Language, Speech, and Hearing Services in Schools, 23, $159-162$.

Studio Audio and Video. (2004). SADiE Disk Editor (Version 5.2.2). [Computer software]. Nashville, TN: Author.

Wan, I., \& Jaeger, J. (2003). The phonological representation of Taiwan Mandarin vowels: A psycholinguistic study. Journal of East Asian Linguistics, 12, 205-257.

Weisleder, P., \& Hodgson, W. R. (1989). Evaluation of four Spanish word-recognition-ability lists. Ear and Hearing, 10 387-392.

Wilson, R. H., \& McArdle, R. A. (2005). Speech signals used to evaluate functional status of the auditory system. Journal of Rehabilitative Research and Development, 42, 79-94.

Wilson, R. H., \& Oyler, A. L. (1997). Psychometric functions for the CID W-22 and NU Auditory Test No. 6. Materials spoken by the same speaker. Ear and Hearing, 18, 430-433.

Zhou, X., \& Marslen-Wilson, W. (1995). Morphological structure in the Chinese mental lexicon. Language and Cognitive Processes, 10, 545-600.

Received October 17, 2007

Accepted December 15, 2007

DOI: $10.1044 / 1059-0889(2008 / 008)$

Contact author: Shawn L. Nissen, Department of Communication Disorders, 138 Taylor Building, Brigham Young University, Provo, UT 84602. E-mail: shawn_nissen@byu.edu.

Individuals or institutions interested in obtaining copies of the Brigham Young University Taiwan Mandarin Speech Audiometry Materials CD may inquire by e-mail to speech_audiometry@byu.edu or by mail to the following address: Department of Communication Disorders, 136 TLRB, Brigham Young University, Provo, UT 84602. 
Appendix A (p. 1 of 2)

Taiwan Mandarin Word Lists in Traditional Chinese Characters and Hanyu Romanization

Male Talker Lists

\begin{tabular}{|c|c|c|c|}
\hline List 1 & List 2 & List 3 & List 4 \\
\hline 後來 我們 & 開發 方法 & 內容 清楚 & 溝通 嚴重 \\
\hline 台灣 能夠 & 加上 昨天 & 開始 成功 & 東西 新聞 \\
\hline 科技 成立 & 然後 原來 & 電話 最近 & 工程 不會 \\
\hline 現在 還是 & 設備 已經 & 或者 不要 & 參加 情況 \\
\hline 負責 過去 & 雖然 國際 & 應該 美國 & 感覺 大學 \\
\hline 相關 老師 & 專業 好像 & 生活 價值 & 成為 能力 \\
\hline 開放 管理 & 了解 課程 & 記者 自我 & 達到 母親 \\
\hline 這樣 需要 & 獲得 動物 & 支持 注意 & 過程 自由 \\
\hline 就是 事件 & 事實 如果 & 社會 怎麼 & 發生 經過 \\
\hline 他們 產生 & 重要 起來 & 今天 學習 & 未來 所以 \\
\hline 當然 處理 & 電腦 一定 & 其實 非常 & 目標 面對 \\
\hline 電視 這裡 & 配合 方式 & 人生 作業 & 增加 文化 \\
\hline 快樂 語言 & 發現 空間 & 投資 不同 & 完全 安全 \\
\hline 變成 希望 & 完成 不能 & 故事 什麼 & 媽媽 解決 \\
\hline 時間 那麼 & 可是 同學 & 受到 不斷 & 學生 下午 \\
\hline 學校 行為 & 或是 同時 & 以後 香港 & 最後 選擇 \\
\hline 接受 時候 & 真正 成長 & 身體 一樣 & 幾乎 繼續 \\
\hline 甚至 也許 & 事業 值得 & 爸爸 原因 & 交通 可以 \\
\hline 改變 但是 & 工作 只要 & 問題 有關 & 觀念 時代 \\
\hline 活動 基本 & 標準 得到 & 傳統 造成 & 準備 没有 \\
\hline 包括 機會 & 程度 都市 & 階段 這麼 & 結果 行動 \\
\hline 公園 特別 & 存在 必須 & 建築 父母 & 計畫 經濟 \\
\hline 朋友 訓練 & 發展 現象 & 教授 政治 & 國家 教育 \\
\hline 先生 一直 & 考慮 喜歡 & 大家 實在 & 可能 覺得 \\
\hline 家庭 另外 & 報導 產品 & 世界 比較 & 本身 出現 \\
\hline
\end{tabular}

\begin{tabular}{|c|c|c|c|c|c|c|c|}
\hline \multicolumn{2}{|c|}{ List 1} & \multicolumn{2}{|c|}{ List 2} & \multicolumn{2}{|c|}{ List 3} & \multicolumn{2}{|c|}{ List 4} \\
\hline hòulái & wǒmen & kāifã & făngfã & nèiróng & qīngchu & gōutōng & yánzhòng \\
\hline táiwān & nénggòu & jiāshàng & zuótiān & kāishĭ & chénggōng & dōngxī & xīnwén \\
\hline kējì & chénglì & ránhòu & yuánlái & diànhuà & zuijìn & gōngchéng & búhuì \\
\hline xiànzài & háishì & shèbèi & yijīing & huòzhě & búyào & cānjiā & qíngkuàng \\
\hline fùzé & guòqù & suīrán & guójì & yīnggāi & měiguó & gănjué & dàxué \\
\hline xiāngguān & lăoshī & zhuānyè & hăoxiàng & shēnghuó & jiàzhí & chéngwéi & nénglì \\
\hline kāifàng & guănlǐ & liăojiě & kèchéng & jìzhě & zìwǒ & dádào & mǔqīn \\
\hline zhèyàng & xūyào & huòdé & dòngwù & zhīchí & zhùyì & guòchéng & zìyóu \\
\hline jiùshì & shìjiàn & shìshí & rúguǒ & shèhuì & zěnme & fāshēng & jīngguò \\
\hline tāmen & chănshēng & zhòngyào & qǐlai & jīntiān & xuéxí & wèilái & suǒyǐ \\
\hline dāngrán & chǔlǐ & diànnăo & yīdìng & qíshí & fēicháng & mùbiāo & miànduì \\
\hline diànshì & zhèlĩ & pèihé & fāngshì & rénshēng & zuòyè & zēngjiā & wénhuà \\
\hline kuàilè & yǔyán & fãxiàn & kōngjiān & tóuzī & bùtóng & wánquán & ānquán \\
\hline biànchéng & xīwàng & wánchéng & bùnéng & gùshì & shénme & māma & jiějué \\
\hline shíjiān & nàme & kěshì & tóngxué & shòudào & bùduàn & xuésheng & xiàwǔ \\
\hline xuéxiào & xíngwéi & huòshì & tóngshí & yǐhòu & xiānggăng & zuihòu & xuănzé \\
\hline jiēshòu & shíhou & zhēnzhèng & chéngzhăng & shēntǐ & yīyàng & jīhū & jìxù \\
\hline shènzhì & yěxŭ & shìyè & zhíde & bàba & yuányīn & jiāotōng & kěyĭ \\
\hline găibiàn & dànshì & gōngzuò & zhǐyào & wèntí & yǒuguān & guānniàn & shídài \\
\hline huódòng & jīběn & biāozhǔn & dédào & chuántǒng & zàochéng & zhǔnbèi & méiyǒu \\
\hline bāokuò & jīhuì & chéngdù & dūshì & jiēduàn & zhème & jiéguǒ & xíngdòng \\
\hline gōngyuán & tèbié & cúnzài & bìxū & jiànzhù & fümǔ & jìhuà & jīngjì \\
\hline péngyou & xùnliàn & fāzhăn & xiànxiàng & jiàoshòu & zhèngzhì & guójiā & jiàoyù \\
\hline xiānsheng & yìzhí & kăolü & xǐhuan & dàjiā & shízài & kěnéng & juéde \\
\hline jiātíng & lìngwài & bàodào & chănpǐn & shijiè & bǐjiào & běnshēn & chūxiàn \\
\hline
\end{tabular}




\section{Appendix A (p. 2 of 2)}

Taiwan Mandarin Word Lists in Traditional Chinese Characters and Hanyu Romanization

Female Talker Lists

\begin{tabular}{|c|c|c|c|}
\hline List 1 & List 2 & List 3 & List 4 \\
\hline 開始 不能 & 電話 不同 & 安全 不断 & 傳統 必須 \\
\hline 工程 成功 & 好像 成為 & 感覺 但是 & 過程 處玨 \\
\hline 問題 得到 & 媽媽 東西 & 然後 都市 & 快樂 非常 \\
\hline 報導 改變 & 專業 溝通 & 參加 觀念 & 爸爸 國際 \\
\hline 當然 還是 & 大學 基本 & 產生 教授 & 大家 過去 \\
\hline 發展 今年 & 電視 幾乎 & 發生 機會 & 管理 階段 \\
\hline 建築 考慮 & 故事 空間 & 交通 就是 & 後來 目標 \\
\hline 教育 時間 & 結果 實際 & 開發 容易 & 記者 生命 \\
\hline 老師 世界 & 了解 條件 & 開放 現在 & 生活 完全 \\
\hline 同學 訓練 & 什麼 新聞 & 同時 壓力 & 事實 學習 \\
\hline 完成 應該 & 相關 嚴重 & 文化 意義 & 選擇 一直 \\
\hline 原來 政治 & 也許 這樣 & 增加 知道 & 自我 原因 \\
\hline 程度 資料 & 成立 成長 & 作業 直接 & 包括 投資 \\
\hline 動物 朋友 & 達到 行動 & 出現 需要 & 除了 造成 \\
\hline 負責 一般 & 方法 昨天 & 公園 努力 & 國家 電腦 \\
\hline 課程 美國 & 活動 存在 & 或者 自由 & 加上 時代 \\
\hline 可是 或是 & 可能 不要 & 科技 語言 & 可以 如何 \\
\hline 面對 現象 & 没有 價值 & 例如 規定 & 歷史 覺得 \\
\hline 清楚 有關 & 目的 運動 & 起來 今天 & 人生 準備 \\
\hline 設備 本身 & 社會 配合 & 身體 值得 & 甚至 母親 \\
\hline 時候 獲得 & 受到 經驗 & 雖然 家庭 & 所以 醫院 \\
\hline 未來 怎麼 & 特別 父母 & 我們 希望 & 他們 其實 \\
\hline 行為 這裡 & 以後 情況 & 學生 經過 & 下午 影響 \\
\hline 只是 公司 & 重要 最近 & 知識 台灣 & 支持 接受 \\
\hline 標準 工作 & 表現 內容 & 變成 團體 & 最後 地方 \\
\hline
\end{tabular}

\begin{tabular}{|c|c|c|c|c|c|c|c|}
\hline \multicolumn{2}{|c|}{ List 1} & \multicolumn{2}{|c|}{ List 2} & \multicolumn{2}{|c|}{ List 3} & \multicolumn{2}{|c|}{ List 4} \\
\hline kāishǐ & bùnéng & diànhuà & bùtóng & ānquán & bùduàn & chuántǒng & bìxū \\
\hline gōngchéng & chénggōng & hăoxiàng & chéngwéi & gănjué & dànshì & guòchéng & chǔlı̌ \\
\hline wèntí & dédào & māma & dōngxī & ránhòu & dūshì & kuàilè & fêicháng \\
\hline bàodào & găibiàn & zhuānyè & gōutōng & cānjiā & guānniàn & bàba & guójì \\
\hline dāngrán & háishì & dàxué & jīběn & chănshēng & jiàoshòu & dàjiā & guòqù \\
\hline fāzhăn & jīnnián & diànshì & jīhū & fāshēng & jīhuì & guănlǐ & jiêduàn \\
\hline jiànzhù & kǎolü & gùshì & kōngjiān & jiāotōng & jiùshì & hòulái & mùbiāo \\
\hline jiàoyù & shíjiān & jiéguǒ & shíjì & kāifã & róngyì & jìzhě & shēngmìng \\
\hline lăoshī & shijiè & liăojiě & tiáojiàn & kāifàng & xiànzài & shēnghuó & wánquán \\
\hline tóngxué & xùnliàn & shénme & xīnwén & tóngshí & yālì & shìshí & xuéxí \\
\hline wánchéng & yīnggāi & xiāngguān & yánzhòng & wénhuà & yìyì & xuănzé & yìzhí \\
\hline yuánlái & zhèngzhì & yěxŭ & zhèyàng & zēngjiā & zhīdao & zìwǒ & yuányīn \\
\hline chéngdù & zīliào & chénglì & chéngzhăng & zuòyè & zhíjiè & bāokuò & tóuzī \\
\hline dòngwù & péngyou & dádào & xíngdòng & chūxiàn & xūyào & chúle & zàochéng \\
\hline fùzé & yībān & fângfã & zuótiān & gōngyuán & nŭlì & guójiā & diànnăo \\
\hline kèchéng & měiguó & huódòng & cúnzài & huòzhě & zìyóu & jiāshàng & shídài \\
\hline kěshì & huòshì & kěnéng & búyào & kējì & yǔyán & kěyǐ & rúhé \\
\hline miànduì & xiànxiàng & méiyǒu & jiàzhí & lìnú & guīdìng & lisshĭ & juéde \\
\hline qīngchu & yǒuguān & mùdì & yùndòng & qǐlai & jīntiān & rénshēng & zhǔnbèi \\
\hline shèbèi & běnshēn & shèhuì & pèihé & shēntǐ & zhíde & shènzhì & mǔqīn \\
\hline shíhou & huòdé & shòudào & jīngyàn & suīrán & jiātíng & suǒyǐ & yīyuàn \\
\hline wèilái & zěnme & tèbié & fümǔ & wǒmen & xīwàng & tāmen & qíshí \\
\hline xíngwéi & zhèlǐ & yǐhòu & qíngkuàng & xuésheng & jīngguò & xiàwǔ & yǐngxiăng \\
\hline zhǐshì & gōngsī & zhòngyào & zuijìn & zhīshi & táiwān & zhīchí & jiēshòu \\
\hline biāozhŭn & gōngzuò & biăoxiàn & nèiróng & biànchéng & tuántĩ & zuihòu & difāng \\
\hline
\end{tabular}




\section{Appendix B (p. 1 of 2)}

\section{Taiwan Mandarin Word Half-Lists in Traditional Chinese Characters and Hanyu Romanization}

Male Talker Half-lists

\begin{tabular}{|c|c|c|c|c|c|c|c|}
\hline $1 \mathrm{~A}$ & 1B & A & $2 B$ & A & $3 B$ & $4 \mathrm{~A}$ & $4 \mathrm{~B}$ \\
\hline 夾 & 彎 & 1 上 & 發 & 容 & 始 & 東西 & $7 x$ \\
\hline 在 & 技 & 然後 & 設備 & 者 & 電話 & ᄃ程 & 加 \\
\hline 責 & 關 & 專業 & 雖然 & 應該 & 生活 & 成為 & 感覺 \\
\hline 樣 & 開放 & 了解 & 獲得 & 支持 & 記者 & 達到 & 過程 \\
\hline 是 & 他們 & 重要 & 事實 & 社會 & 今天 & 未來 & 發生 \\
\hline 視 & 當然 & 電腦 & 配合 & 人生 & 其實 & 目標 & 增加 \\
\hline 樂 & 變成 & 完成 & 發現 & 投資 & 故事 & 媽媽 & 完全 \\
\hline 校 & 間 & 可是 & 或是 & 以後 & 受到 & 學生 & 最後 \\
\hline 受 & t至 & 事業 & 真正 & 身體 & 爸爸 & 交通 & 幾乎 \\
\hline 動 & 變 & 工作 & 票準 & 傳統 & 問題 & 觀念 & 主備 \\
\hline 括 & 園 & 存在 & 程度 & 段 & 建築 & 畫 & 吉果 \\
\hline 生 & 市 & 發展 & 考慮 & & 受 & & 厂能 \\
\hline 庭 & 們 & 去 & 報導 & 界 & 楚 & 嚴重 & 太身 \\
\hline 成立 & 能夠 & 昨天 & 原來 & 最近 & 成功 & 新聞 & 不會 \\
\hline 還是 & 過去 & 國際 & 已經 & 不要 & 美國 & 大學 & 情況 \\
\hline 管理 & 老師 & 好像 & 課程 & 自我 & 價值 & 能力 & 母親 \\
\hline 需要 & 事件 & 如果 & 動物 & 注意 & 怎麼 & 經過 & 自由 \\
\hline 處理 & 產生 & 起來 & 一定 & 非常 & 學習 & 所以 & 面對 \\
\hline 這裡 & 語言 & 空間 & 方式 & 作業 & 同 & 安全 & 文化 \\
\hline 坚 & 希望 & 不能 & 同學 & 不斷 & 什麼 & 解決 & 下午 \\
\hline 為 & 時候 & 成長 & 同時 & 香港 & 一樣 & 繼續 & 選擇 \\
\hline 但是 & 也許 & 值得 & 只要 & 有關 & 原因 & 可以 & 時代 \\
\hline 基本 & 機會 & 都市 & 得到 & 造成 & 這麼 & 行動 & 没有 \\
\hline 訓練 & 特別 & 必須 & 現象 & 政治 & 父母 & 經濟 & 教育 \\
\hline 一直 & 另外 & 產品 & 喜歡 & 實在 & 比較 & 出現 & 覺得 \\
\hline
\end{tabular}

\begin{tabular}{|c|c|c|c|c|c|c|c|}
\hline $1 \mathrm{~A}$ & 1B & $2 \mathrm{~A}$ & $2 B$ & $3 \mathrm{~A}$ & $3 B$ & $4 \mathrm{~A}$ & $4 B$ \\
\hline hòulái & táiwān & jiāshàng & kāifā & nèiróng & kāishǐ & dōngxī & gōutōng \\
\hline xiànzài & kējì & ránhòu & shèbèi & huòzhě & diànhuà & gōngchéng & cānjiā \\
\hline fùzé & xiāngguān & zhuānyè & suīrán & yīnggāi & shēnghuó & chéngwéi & gănjué \\
\hline zhèyàng & kāifàng & liăojiě & huòdé & zhīchí & jìzhě & dádào & guòchéng \\
\hline jiùshì & tāmen & zhòngyào & shìshí & shèhuì & jīntiān & wèilái & fāshēng \\
\hline diànshì & dāngrán & diànnăo & pèihé & rénshēng & qíshí & mùbiāo & zēngjiā \\
\hline kuàilè & biànchéng & wánchéng & fāxiàn & tóuzī & gùshì & māma & wánquán \\
\hline xuéxiào & shíjiān & kěshì & huòshì & yǐhòu & shòudào & xuésheng & zuìhòu \\
\hline jiēshòu & shènzhì & shìyè & zhēnzhèng & shēntǐ & bàba & jiāotōng & jīhū \\
\hline huódòng & găibiàn & gōngzuò & biāozhǔn & chuántǒng & wèntí & guānniàn & zhǔnbèi \\
\hline bāokuò & gōngyuán & cúnzài & chéngdù & jiēduàn & jiànzhù & jìhuà & jiéguǒ \\
\hline xiānsheng & péngyou & fāzhăn & kăolǜ & dàjiā & jiàoshòu & guójiā & kěnéng \\
\hline jiātíng & wǒmen & fāngfã & bàodào & shìjiè & qīngchu & yánzhòng & běnshēn \\
\hline chénglì & nénggòu & zuótiān & yuánlái & zuìjìn & chénggōng & xīnwén & búhuì \\
\hline háishì & guòqù & guójì & yǐjīng & búyào & měiguó & dàxué & qíngkuàng \\
\hline guănlǐ & lăoshī & hăoxiàng & kèchéng & zìwǒ & jiàzhí & nénglì & mǔqīn \\
\hline xūyào & shìjiàn & rúguǒ & dòngwù & zhùyì & zěnme & jīngguò & zìyóu \\
\hline chǔlǐ & chănshēng & qǔlai & yīdìng & fềicháng & xuéxí & suǒyǐ & miànduì \\
\hline zhèlǐ & yǔyán & kōngjiān & fāngshì & zuòyè & bùtóng & ānquán & wénhuà \\
\hline nàme & xīwàng & bùnéng & tóngxué & bùduàn & shénme & jiějué & xiàwŭ \\
\hline xíngwéi & shíhou & chéngzhăng & tóngshí & xiānggăng & yīyàng & jìxù & xuănzé \\
\hline dànshì & yěxǔ & zhíde & zhǐyào & yǒuguān & yuányīn & kěyǐ & shídài \\
\hline jīběn & jīhuì & dūshì & dédào & zàochéng & zhème & xíngdòng & méiyǒu \\
\hline xùnliàn & tèbié & bìxū & xiànxiàng & zhèngzhì & fùmú & jīngjì & jiàoyù \\
\hline yìzhí & lìngwài & chănpǐn & Xǐhuan & shízài & bijiào & chūxiàn & juéde \\
\hline
\end{tabular}




\section{Appendix B (p. 2 of 2)}

Taiwan Mandarin Word Half-Lists in Traditional Chinese Characters and Hanyu Romanization

Female Talker Half-lists

\begin{tabular}{|c|c|c|c|c|c|c|c|}
\hline $1 \mathrm{~A}$ & 1B & $2 \mathrm{~A}$ & $2 \mathrm{~B}$ & $3 \mathrm{~A}$ & $3 \mathrm{~B}$ & $4 \mathrm{~A}$ & 4B \\
\hline 工程 & 開始 & 電話 & 好像 & 感覺 & 安全 & 傳統 & 過程 \\
\hline 問題 & 報導 & 專業 & 媽媽 & 然後 & 參加 & 爸爸 & 快樂 \\
\hline 發展 & 當然 & 大學 & 電視 & 發生 & 產生 & 大家 & 管理 \\
\hline 建築 & 教育 & 結果 & 故事 & 交通 & 開發 & 記者 & 後來 \\
\hline 同學 & 老師 & 了解 & 什麼 & 同時 & 開放 & 生活 & 事實 \\
\hline 完成 & 原來 & 也許 & 相關 & 文化 & 增加 & 自我 & 選擇 \\
\hline 動物 & 程度 & 成立 & 達到 & 出現 & 作業 & 包括 & 除了 \\
\hline 負責 & 課程 & 活動 & 方法 & 公園 & 或者 & 加上 & 國家 \\
\hline 面對 & 可是 & 可能 & 没有 & 例如 & 科技 & 可以 & 歷史 \\
\hline 清楚 & 設備 & 社會 & 目的 & 起來 & 身體 & 甚至 & 生 \\
\hline 未來 & 時候 & 受到 & 特別 & 我們 & 雖然 & 所以 & 他們 \\
\hline 行為 & 只是 & 重要 & 以後 & 學生 & 知識 & 支持 & 下午 \\
\hline 不能 & 標準 & 表現 & 不同 & 不斷 & 變成 & 最後 & 必須 \\
\hline 成功 & 得到 & 東西 & 成為 & 但是 & 都市 & 非常 & 處理 \\
\hline 還是 & 改變 & 溝通 & 基本 & 教授 & 觀念 & 國際 & 過去 \\
\hline 今年 & 考慮 & 空間 & 幾乎 & 機會 & 就是 & 目標 & 階段 \\
\hline 世界 & 時間 & 實際 & 條件 & 現在 & 容易 & 生命 & 完全 \\
\hline 訓練 & 應該 & 嚴重 & 新聞 & 壓力 & 意義 & 一直 & 學習 \\
\hline 資料 & 政治 & 這樣 & 成長 & 直接 & 知道 & 原因 & 投資 \\
\hline 朋友 & 一般 & 昨天 & 行動 & 需要 & 努力 & 電腦 & 造成 \\
\hline 或是 & 美國 & 存在 & 不要 & 語言 & 自由 & 時代 & 如何 \\
\hline 現象 & 有關 & 運動 & 價值 & 規定 & 今天 & 準備 & 覺得 \\
\hline 獲得 & 本身 & 配合 & 經驗 & 家庭 & 值得 & 母親 & 醫院 \\
\hline 怎麼 & 這裡 & 情況 & 父母 & 希望 & 經過 & 影響 & 其實 \\
\hline 工作 & 公司 & 最近 & 内容 & 團體 & 台灣 & 接受 & 地方 \\
\hline
\end{tabular}

\begin{tabular}{|c|c|c|c|c|c|c|c|}
\hline $1 \mathrm{~A}$ & 1B & $2 \mathrm{~A}$ & $2 \mathrm{~B}$ & $3 \mathrm{~A}$ & 3B & $4 \mathrm{~A}$ & 4B \\
\hline gōngchéng & kāishǐ & diànhuà & hăoxiàng & gănjué & ānquán & chuántǒng & guòchéng \\
\hline wèntí & bàodào & zhuānyè & māma & ránhòu & cānjiā & bàba & kuàilè \\
\hline făzhăn & dāngrán & dàxué & diànshì & fāshēng & chănshēng & dàjiā & guănlǐ \\
\hline jiànzhù & jiàoyù & jiéguǒ & gùshì & jiāotōng & kāifā & jìzhě & hòulái \\
\hline tóngxué & lăoshī & liăojiě & shénme & tóngshí & kāifàng & shēnghuó & shìshí \\
\hline wánchéng & yuánlái & yěxŭ & xiāngguān & wénhuà & zēngjiā & zìwǒ & xuănzé \\
\hline dòngwù & chéngdù & chénglì & dádào & chūxiàn & zuòyè & bāokuò & chúle \\
\hline fùzé & kèchéng & huódòng & fāngfã & gōngyuán & huòzhě & jiāshàng & guójiā \\
\hline miànduì & kěshì & kěnéng & méiyŏu & lìrú & kējì & kěyĭ & lìshǐ \\
\hline qīngchu & shèbèi & shèhuì & mùdì & qǐlai & shēntǐ & shènzhì & rénshēng \\
\hline wèilái & shíhou & shòudào & tèbié & wǒmen & suîrán & suǒyǐ & tāmen \\
\hline xíngwéi & zhǐshì & zhòngyào & yǐhòu & xuésheng & zhīshi & zhīchí & xiàwǔ \\
\hline bùnéng & biāozhǔn & biăoxiàn & bùtóng & bùduàn & biànchéng & zuìhòu & bìxū \\
\hline chénggōng & dédào & dōngxī & chéngwéi & dànshì & dūshì & fêicháng & chǔlǐ \\
\hline háishì & găibiàn & gōutōng & jīběn & jiàoshòu & guānniàn & guójì & guòqù \\
\hline jīnnián & kăolü & kōngjiān & jīhū & jīhuì & jiùshì & mùbiāo & jiēduàn \\
\hline shijiè & shíjiān & shíjì & tiáojiàn & xiànzài & róngyì & shēngmìng & wánquán \\
\hline xùnliàn & yīnggāi & yánzhòng & xīnwén & yālì & yìyì & yìzhí & xuéxí \\
\hline zîliào & zhèngzhì & zhèyàng & chéngzhăng & zhíjiè & zhīdao & yuányīn & tóuzī \\
\hline péngyou & yībān & zuótiān & xíngdòng & xūyào & nǔlì & diànnăo & zàochéng \\
\hline huòshì & měiguó & cúnzài & búyào & yǔyán & zìyóu & shídài & rúhé \\
\hline xiànxiàng & yǒuguān & yùndòng & jiàzhí & guīdìng & |jīntiān & zhǔnbèi & juéde \\
\hline huòdé & běnshēn & pèihé & jīngyàn & jiātíng & zhíde & mŭqīn & yīyuàn \\
\hline zěnme & zhèlǐ & qíngkuàng & fümǔ & xīwàng & jīngguò & yǐngxiăng & qíshí \\
\hline gōngzuò & gōngsī & zuijìn & nèiróng & tuántǐ & táiwān & jiēshòu & difāng \\
\hline
\end{tabular}




\section{Word Recognition Materials for Native Speakers of Taiwan Mandarin}

Shawn L. Nissen, Richard W. Harris, and Alycia Dukes

Am J Audiol 2008; 17;68-79

DOI: $10.1044 / 1059-0889(2008 / 008)$

The references for this article include 3 HighWire-hosted articles which you can access for free at: http://aja.asha.org/cgi/content/full/17/1/68\#BIBL

\section{This information is current as of August 14, 2012}

This article, along with updated information and services, is

located on the World Wide Web at:

http://aja.asha.org/cgi/content/full/17/1/68

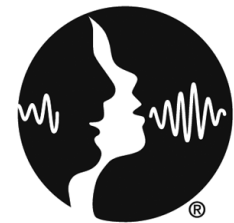

